\section{Effect of Surface Active Substances on the Polarographic Catalytic Hydrogen Current of Bovine Serum Albumin}

\author{
Tokuji IKedA and Mitsugi SendA \\ Department of Agricultural Chemistry, \\ College of Agriculture, Kyoto University, \\ Kyoto 606, Japan
}

Received November 14, 1977

Proteins yield characteristic polarographic currents, usually called "presodium wave or presodium current,"1) due to catalytic hydrogen evolution at the dropping mercury electrode; sulfhydryl and disulfidic groups $^{\text {2) }}$ and/or nitrogenous groups ${ }^{3,4)}$ in the proteins are considered to be responsible for the catalytic activity. In this study the presodium current of bovine serum albumin (BSA) in the presence of surface active substances, sodium dodecylsulfate (SDS), dodecyltrimethylammonium chloride (DTMAC) or dodecanol has been investigated with reference to the interaction of the protein molecule with the surface active substance. ${ }^{5, B)}$

Experiments were carried out in phosphate buffer $(0.08 \mathrm{M})$ of $\mathrm{pH} 6.75$ containing $0.04 \mathrm{M} \mathrm{NaCl}$ at $25^{\circ} \mathrm{C}$. All chemicals were of a reagent grade quality. Stock solution of BSA (about $10^{-4} \mathrm{M}$ ) was prepared by dissolving BSA (Armour product lot M3G9578) in distilled water and stored in a refrigerator at $5^{\circ} \mathrm{C}$. The concentration was checked spectrophotometrically. The polarograms were recorded, without deaeration, usually 12 to $24 \mathrm{hr}$ after preparation of a test solution. It has preliminarily been ascertained that the polarograms remain unchanged on and after several hours down to $48 \mathrm{hr}$ from the preparation of test solutions. D. c. polarograms were recorded with a Yanagimoto polarograph, model p-8. A.c. polarograms were recorded with a lock-in amplifier, NF LI-5728. Potentials were reffered to a saturated calomel electrode (SCE). The currents were recorded at the maximum growth of the dropping mercury electrode. The capillary characteristics (open circuit) were $m=1.45 \mathrm{mg} / \mathrm{s}$ and $t=8.1 \mathrm{~s}$ at the mercury column height of $60 \mathrm{~cm}$.

Figure 1 shows d. c. polarograms of BSA in the absence and presence of SDS. The height of the presodium current was measured at $-1.9 \mathrm{~V}$ with correction for the residual current and plotted against the logarithm of SDS concentrations. Figure 2 shows i vs. $\log \mathrm{C}_{\text {SDs }}$ curve obtained with $4 \times 10^{-7} \mathrm{M}$ BSA in $0.08 \mathrm{M}$ phosphate buffer and $0.04 \mathrm{M} \mathrm{NaCl}$. Similar results were obtained with $4 \times 10^{-8} \mathrm{M}$ BSA solution. In general, polarographic presodium current decreased

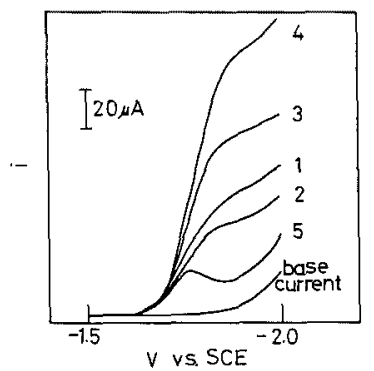

FiG. 1. D. c. Polarograms of BSA $\left(4 \times 10^{-7} \mathrm{M}\right)$ in $0.08 \mathrm{M}$ Phosphate Buffer $(\mathrm{pH} 6.75$ ) and $0.04 \mathrm{M} \mathrm{NaCl}$, SDS Concentration: $1,0,2,8 \times 10^{-8} \mathrm{M} ; 3,8 \times 10^{-5} \mathrm{M}$; $4,1.6 \times 10^{-4} \mathrm{M} ; 5,8 \times 10^{-4} \mathrm{M}$.

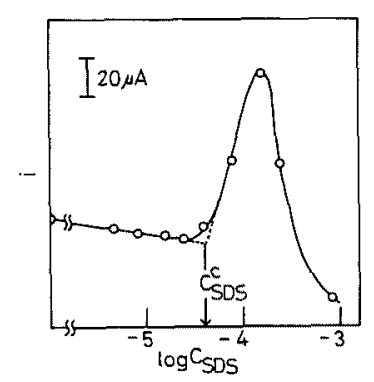

FIG. 2. Dependence of the Height of the Presodium Current on the Logarithm of SDS Concentration.

slightly with increasing SDS concentration up to about $4 \times 10^{-5} \mathrm{M}$, then increased steeply and reached a maximum at a certain SDS concentration, beyond which the current decreased again steeply with increasing SDS concentration.

A. c. polarographic results which agreed in general with those of $\mathrm{Eda}^{T}$ indicate no adsorption of dodecylsulfate anion on mercury electrode at the potential where the presodium current is observed. On the other hand BSA molecule seems to adsorb weakly on mercury electrode in these potential region. ${ }^{B 2}$

According to Reynolds et al., ${ }^{\theta}$, the native BSA binds approximately ten anions of dodecylsulfate at the lower concentration of SDS (below about $6 \times 10^{-5} \mathrm{M}$ at $\mathrm{pH}$ $5.6,23^{\circ} \mathrm{C}$ ). At higher concentration of SDS a conformational change occurs in the BSA molecule and the denatured BSA-SDS complex is characterized by a high binding ratio. ${ }^{5}$ The binding is micellar one and the complex becomes a highly anionic particle with further increase in SDS concentration. ${ }^{\theta, 10,11,12)}$

In view of these considerations the slight decrease of the currents at the lower concentrations of SDS may be ascribed to the decreased adsorption of BSA molecule on the electrode surface; the anionic charges on native BSA molecule would make difficult the "preferable" adsorption of BSA on the negatively charged surface of the mercury electrode. The increase of the current with 


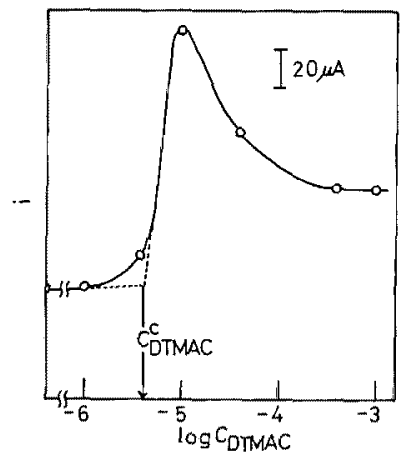

Fig. 3. Dependence of the Height of the Presodium Current on the Logarithm of DTMAC Concentration.

increasing SDS concentration can be interpreted as that the binding of SDS to BSA induces a conformational change of BSA which may result in the exposure of more electro-active groups to the surface of the BSA molecule. By further addition of SDS, some electroactive groups of the unfolded BSA molecule may become to be covered with the dodecyl-sulfate anion bound to BSA molecule. The high anionic charge will also promote the desorption of BSA from the electrode surface. These may explain the sharp decrease of the current at the higher SDS concentrations. In conclusion, the critical SDS concentration, $C_{\text {SDS }}^{\text {C }}(4.2 \times$ $\left.10^{-5} \mathrm{M}\right)$ shown in Fig. 2 may correspond to the concentration at which the conformational change begins to occur in the BSA molecule. The SDS concentrations where the sharp decrease of the current occurs may corresponds to those where an increase in micellar binding occurs of dodecylsulfate anion to the unfolded BSA molecule.

A cationic surfactant, DTMAC, has also an appreciable effect on the presodium current of BSA. Figure 3 shows i vs. $\log C_{\text {DTMAC }}$ curve obtained with $4 \times 10^{-7} \mathrm{M}$ BSA in $0.08 \mathrm{M}$ phosphate buffer and $0.04 \mathrm{M} \mathrm{NaCl}$. The initial current decrease, as observed in $\mathrm{i} v s . \log \mathrm{C}_{\mathrm{SDS}}$ curve (Fig. 2), was not observed in i vs. $\log \mathrm{C}_{\mathrm{DTMAO}}$ curve. This difference may be interpreted as due to the difference in the charge of the surfactants. Though the detail is not known on the interaction of a protein molecule with DTMAC, ${ }^{13)}$ we may expect that the binding of DTMAC with BSA should induce a con- formational change with resulting increase of the catalytic current. The critical concentration of DTMAC, $C_{\mathrm{DTMAC}}^{\mathrm{O}}$, was determined to be $4.2 \times 10^{-8} \mathrm{M}$ from the i vs. $\log C_{\text {DIMAC }}$ curve in Fig. 3. The plateau following the maximum may also be attributable to the increased adsorption of BSA due to the high cationic charge on the unfolded BSA molecule. No indication of the adsorption of DTMAC on mercury electrode in the potential range where the presodium current appeared was observed on imaginary-part a. c. polarograms.

Dodecanol had no appreciable effect on the presodium current of BSA even in saturated solution of dodecanol of $0.08 \mathrm{M}$ phosphate buffer ( $\mathrm{pH}$ 6.75) including $0.04 \mathrm{M} \mathrm{NaCl}$, indicating the conformational change of BSA molecule is not induced in the studied solution of dodecanol.

\section{REFERENCES}

1) J. Heyrovský and J. Kŭta, "Principle of Polarography," Academic Press, N.Y. and London, 1966, p. 408.

2) R. Brdicka, Collect. Czech. Chem. Commun., 8, 366 (1936).

3) G. J. Miller, Biochem J., 53, 385, 393 (1953).

4) I. M. Kolthoff, K. Yamashita and T. B. Hie, J. Electroanal. Chem., 63, 393 (1975).

5) J. Steinhardt and J. A. Reynolds, "Multiple Equilibria in Proteins," Academic Press, N.Y. and London, 1969, p 234.

6) T. Takagi, K. Shirahama, K. Tsujii and K. Kubo, Tanpakushitsu Kakusan Koso, 21, 811 (1976).

7) K. Eda, Nippon Kagaku Zasshi, 80, 349 (1957).

8) M. Senda, T. Ikeda and H. Kinoshita, Bioelectrochem. Bioenerg., 3, 253 (1976).

9) J. A. Reynolds, S. Herbert, H. Polet and J. Steinhardt, Biochemistry, 6, 937 (1967).

10) J. Oakes, J. C. S. Faraday I, 70, 2200 (1974).

11) K. Shirahama K. Tsujii and T. Takagi, J. Biochem., 75, 309 (1974).

12) T. Takagi, K. Tsujii and K. Shirahama, ibid., 77, 939 (1975).

13) A. V. Few, R. H. Ottewill and H.C. Parreira, Biochim. Biophys. Acta, 18, 136 (1955). 